\title{
New and rare lichens and allied fungi from Arkhangelsk region, North-West Russia
}

\author{
Viktoria N. Tarasova ${ }^{1}$, Liudmila A. Konoreva ${ }^{2}$, Mikhail P. Zhurbenko', \\ Tatiana N. Pystina ${ }^{4}$, Sergei V. Chesnokov ${ }^{5}$, Vera I. Androsova ${ }^{1}$, Angella V. Sonina ${ }^{1}$, \\ Natalia A. Semenova ${ }^{4}$, Andrei A. Valekzhanin ${ }^{6}$ \\ ${ }^{1}$ Department of Botany and Plant Physiology, Petrozavodsk State University, 33 Lenin Str., 185910 Petrozavodsk, Russia. \\ E-mails: tarasova1873@gmail.com, vera.androsova28@gmail.com,angella_sonina@mail.ru \\ 2Polar-alpine Botanical Garden-Institute, 184250 Murmansk Region, Kirovsk. E-mail: ajdarzapov@yandex.ru \\ ${ }^{3}$ Laboratory of the Systematics and Geography of Fungi, Komarov Botanical Institute, Russian Academy of Sciences, 2 \\ Professor Popov Str., 197376 St. Petersburg, Russia. E-mail: zhurb58@gmail.com \\ ${ }^{4}$ Department of Flora and Vegetation of the North, Institute of Biology of Komi Scientific Centre of the Ural Branch of \\ the Russian Academy of Sciences, 28 Kommunisticheskaya Str., 167982 Syktivkar, Russia. \\ E-mail: t.pystina@ib.komisc.ru, semenova@ib.komisc.ru \\ ${ }^{5}$ Laboratory of Lichenology and Bryology, Komarov Botanical Institute, Russian Academy of Sciences, \\ 2 Professor Popov Str., 197376 St. Petersburg, Russia \\ ${ }^{6}$ N. Laverov Federal Center for Integrated Arctic Research RAS (FCIARctic), 23 Severnoy Dviny Embenkment, \\ 163000 Arkhangelsk, Russia. E-mail: valekzhanin13@gmail.com
}

\begin{abstract}
Thirty-one lichen-forming fungi, 12 lichenicolous fungi, and 5 non-lichenized fungi are reported as new for Arkhangelsk Region; 7 species are new for its mainland area. Micarea fallax is reported for the first time for Russia; $M$. laeta and M. pusilla are new for the European part of Russia. The second finding of Nicropuncta rugulosa for Russia is recorded; microconidia are first observed in this species. The records of ten species which have been included in the new edition of the Red Data Book of the Arkhangelsk Region (2020) are presented. Nephromopsis laureri from the Red Data Book of the Russian Federation (2008) and Leptogium rivulare from the IUCN Red List are reported for the first time for Arkhangelsk Region.
\end{abstract}

Keywords: Leptogium rivulare, Micarea fallax, Micarea laeta, Micarea pusilla, Nephromopsis laureri, Nicropuncta rugulosa, Red Data Book, Vodlozersky National Park

\section{INTRODUCTION}

The vast territory of Arkhangelsk Region of Russia (589.9 thousand $\mathrm{km}^{2}$ ), including the flat area of the northern and middle boreal zone with a relatively high share of old-growth forests, the sea coast, limestone outcrops, relatively high rocky outcrops of Baltic Shield, as well as the large territory of the islands in the Arctic, suggests high species richness of lichens. The lichen diversity of Arkhangelsk Region is still poorly known compared with other regions of Russia; there is still no checklist of lichens for this territory, and therefore the corresponding chapter in the regional Red Data Book was difficult to complete for a long time. In the previous edition of the Red Data Book of the Arkhangelsk Region (Novoselov, 2008), only ten species of lichens were included. By contrast, in the neighboring Murmansk Region (Konstantinova et al., 2014), 84 species are protected; in the Republic of $\mathrm{Ka}-$ relia (Ivanter \& Kuznetsov, 2007) - 77 species, and in the Republic of Komi (Degteva, 2019) - 85 species are included.

Our earlier publications (Tarasova et al., 2015, 2016) contain detailed overview of history of lichenological studies in the territory of Arkhangelsk Region. Currently, diversity of lichens and allied fungi in Arkhangelsk Region is becoming increasingly studied (Konoreva et al., 2019b; Tarasova et al., 2019). Annually several expeditions are organized to different parts of the region. In 2019, based on detailed study of literature data, herbarium material and private data, the list of lichens including 56 species was compiled for the new edition of the Red Data Book of the Arkhangelsk Region (Anufriev et al., 2020).

Our study aims to present new and rare lichens and allied fungi from Arkhangelsk Region, North-West Russia. 


\section{MATERIALS AND METHODS}

The study is based on the materials collected during 15 expeditions in 2010-2019. Totally, 66 localities from different districts of Arkhangelsk Region were investigated (Appendix; Fig. 1).

The collected material was identified using a standard microscopic technique and spot tests. Microscopical examination of lichenicolous fungi was carried out using a Stemi 2000-CS dissecting microscope and a Zeiss Axio Imager A1 compound microscope with interference contrast, fitted with an AxioCam MRc5 digital camera. The length and breadth of ascospores are given as (min-) $\{\mathrm{X}-\mathrm{SD}\}-\{\mathrm{X}+\mathrm{SD}\}(-\max )$, where "min" and "max" are the extreme observed values, $\mathrm{X}$ the arithmetic mean and SD the corresponding standard deviation, followed by the number of measurements (n). The length/breadth ratio is indicated in the same way. The lichen substances of Micarea species were identified by a standard technique of high performance thin-layer chromatography (HPTLC) in the Laboratory of Lichenology and Bryology of Komarov Botanical Institute of RAS (St. Petersburg) using solvent system C (Orange et al., 2001). The crystalline granules of Micarea species were investigated by using a compound microscope with polarization filters. The cited specimens are deposited in the Herbarium of Petrozavodsk State University (PZV), Komarov Botanical Institute RAS (LE) and Komi Research Centre (SYKO).

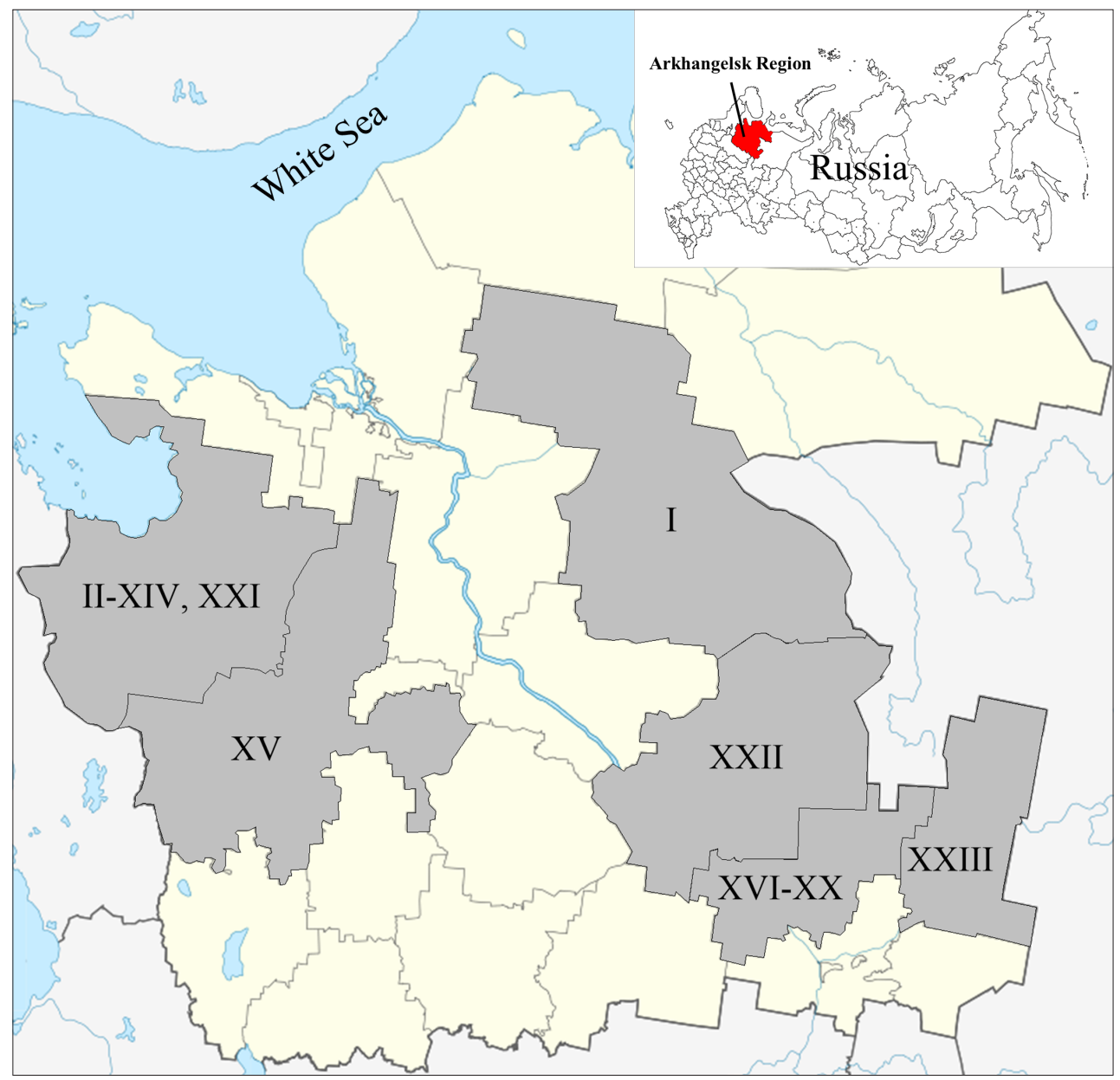

Fig. 1. Collection sites (I-XXIII, detailed data are presented in Appendix 1). 


\section{LIST OF SPECIES}

The taxa are arranged in the alphabetical order; nomenclature of lichens and non-lichenized fungi mainly follows Nordin et al. (2011), nomenclature of lichenicolous fungi follows Diederich et al. (2018). For each species the localities, habitat types and substrate are listed (Appendix). The main phorophytes for listed lichens were spruce (Picea obovata Ledeb. \& Picea abies (L.) Karst.), birch (Betula pubescens Ehrh.), aspen (Populus tremula L.), black alder (Alnus glutinosa (L.) Gaertn), bird cherry (Prunus padus L.), fir (Abies sibirica Ledeb), willow (Salix caprea L.) and pine (Pinus sylvestris L.). Lichen substances are given for TLC-analyzed species. Abbreviations and symbols: \# - lichenicolous fungi; + - nonlichenized fungi; ! - new species for Arkhangelsk Region; RA - species included in the Red Data Book of Arkhangelsk Region (Anufriev et al., 2020); PZV - herbarium of Petrozavodsk State University, LE - herbarium of Komarov Botanical Institute RAS, SYKO - herbarium of Komi Research Centre; $1 / \mathrm{b}$ - length/breadth ratio of ascospores, pol+(-) - crystals studied in polarized light are visible (or none detected).

!\# Abrothallus bertianus De Not. - on Melanohalea olivacea (apothecia, thallus), V: 37, LE 310126. - This is a common subcosmopolitan species mainly reported from Melanelixia and Melanohalea (Brackel, 2014). Distribution in neighboring territories: Leningrad Region (Himelbrant et al., 2018), Republic of Karelia (Zhurbenko \& Ahti, 2005), and Yamal-Nenets Autonomous Area (Zhurbenko, 2008).

!\# Bachmanniomyces punctum (A. Massal.) Diederich \& Pino-Bodas - on Cladonia furcata (basal squamules), VI: 38, LE 310124. - This is a common cosmopolitan species confined to Cladonia (Brackel, 2014; Zhurbenko \& Pino-Bodas, 2017). Distribution in neighboring territories: Leningrad Region (Himelbrant et al., 2013), Murmansk Region (Urbanavichus et al., 2008), Republic of Komi (Zhurbenko, 2004), and YamalNenets Autonomous Area (Zhurbenko, 2008).

! Biatora vaccinilcola (Tønsberg) Printzen - on spruce twigs, XXI: 56, XXII: 57, SYKO. - A rare species in Russia. Distribution in Russia: Republic of Komi (Hermansson et al., 2006), and Kamchatka Territory (Himelbrant et al., 2009).

! Biatora vernalis (L.) Fr. - on mossy trunk base of spruce, I: 1, PZV. - A common boreal species reported from most regions of Russia (Urbanavichus, 2010). Distribution in neighboring territories: Leningrad Region (Kuznetsova et al., 2007a), Republic of Karelia (Fadeeva et al., 2007), and Republic of Komi (Gruzdev et al., 2005).

! CHAENotheCA GRACILlima (Vain.) Tibell - on wood of stand and fallen dead spruce and birch, less often on bark of living spruce trees, I: 2-9, PZV, on dead wood of spruce stump, XXII: 57, SYKO; RA. - A rare, specialist species, i.e. adapted to specific habitat requirements of biologically valuable old-growth forests (Andersson et al., 2009) and is vulnerable to habitat disturbance (managed forests). Distribution in neighboring territories: Murmansk Region (Urbanavichus et al., 2008), Leningrad Region (Kuznetsova et al., 2007a), Republic of Karelia (Fadeeva et al., 2007), Kostroma Region (Urbanavichene \& Urbanavichus, 2019), and Republic of Komi (Hermansson et al., 1998).

! Chaenotheca sphaerocephala Nádv. - on branches of spruce, I: 10, IV: 35, PZV, RA. Distribution in neighboring territories: Kostroma Region (Kuznetsova \& Skazina, 2010), Leningrad Region (Kuznetsova et al., 2007b; Sorokina et al., 2017), and Republic of Komi (Gruzdev et al., 2005).

Chaenotheca Phaeocephala (Turner) Th. Fr. - on bark of spruce, I: 2, 11-12, 7, 13-15, IV: 36, PZV, RA. - This species was previously known in Arkhangelsk Region only from Onezhsky District (Tarasova et al., 2019). Distribution in neighboring territories: Republic of Karelia (Fadeeva et al., 2007), Republic of Komi (Pystina, 2003), and Leningrad Region (Kuznetsova et al., 2007a).

! Chaenotheca xyloxena Nádv. - on dead wood, I: 5, 7, PZV. - A common species reported from most regions of Russia (Urbanavichus, 2010). Distribution in neighboring territories: Murmansk Region (Urbanavichus et al., 2008), Leningrad Region (Himelbrant, 2016), Republic of Karelia (Fadeeva et al., 2007), and Republic of Komi (Hermansson et al., 1998).

+ Chaenothecopsis fennica (Laurila) Tibell. - on stump of pine, XXIII: 60, SYKO. - A rare, specialist species of biologically valuable old-growth forests (Andersson et al., 2009). Formerly known in Arkhangelsk Region only from Onezhsky District (Tarasova et al., 2019). Distribution in neighboring territories: Republic of Karelia 
(Tarasova et al., 2016), Republic of Komi (Hermansson et al., 2006), and Murmansk Region (Konstantinova et al., 2014).

!+ Chaenothecopsis Rubescens Vain. - on aspen wood, XVI: 50, SYKO. - Distribution in neighboring territories: Murmansk Region (Urbanavichus \& Urbanavichene, 2018), Tver Region (Notov et al., 2019), and Republic of Komi (Hermansson et al., 2006).

\# Endococcus PROPINQUUs (Körb.) D. Hawksw. on thalli of Porpidia cf. cinereoatra, $P$. cinereoatra and P. crustulata, VI: 39, LE 310120, LE 310122, LE 310121. - The ascospores are slightly larger than those reported in Triebel (1989), viz. $(9.2-) 10.5-12.9(-14.8) \times(5.2-) 5.9-7.5(-9.3) \mu \mathrm{m}$, $1 / \mathrm{b}=(1.3-) 1.5-2.1(-2.5)(\mathrm{n}=71$, in water $)$ vs. $(7.5-) 8.5-12.5(-13) \times 5-7(-7.5) \mu \mathrm{m}$. This is a common cosmopolitan species typically growing on Porpidia (Brackel, 2014; Triebel, 1989). Previously known in Arkhangelsk Region only from its Arctic part (Franz Josef Land and Novaya Zemlya; Lynge, 1928; Zhurbenko \& Santesson, 1996). Distribution in neighbouring territories: Leningrad region (Brenner, 1885), Murmansk Region (Zhurbenko, 2008), Republic of Karelia (Zhurbenko \& Himelbrant, 2002), and YamalNenets Autonomous Area (Zhurbenko, 2002).

\# Epicladonia sandstedei (Zopf) D. Hawksw. - on Cladonia coniocraea (podetia, podetial squamules) on mossy boulder of hillside, VII: 40, LE 310128. - A common subcosmopolitan species confined to Cladonia (Brackel, 2014; Zhurbenko \& Pino-Bodas, 2017). Previously known in Arkhangelsk Region only from its Arctic part (Nenets Autonomous Area; Zhurbenko \& Pino-Bodas, 2017). Distribution in neighboring territories: Leningrad Region (Himelbrant et al., 2016), Murmansk Region (Zhurbenko \& Himelbrant, 2002), and Republic of Komi (Zhurbenko, 2004).

!\# Heterocephalacria PHYSCIACEARUM (Diederich) Millanes \& Wedin - on Physcia aipolia (thallus) growing on willow, VIII: 41, LE 310132. - A common cosmopolitan species (Diederich, 1996; Brackel, 2014). Distribution in neighboring territories: Leningrad Region (Stepanchikova et al., 2017), Republic of Karelia (Alstrup et al., 2005), and Republic of Komi (Alstrup, 2014).

! Lecanactis abietina (Ach.) Körb. - on bark of spruce, XX: 54, SYKO. - Distribution in neighboring territories: Republic of Komi (Hermans- son et al., 1998), Republic of Karelia (Fadeeva et al., 2007), and Leningrad Region (Lebedeva, 2005).

! Leptogium Rivulare (Ach.) Mont. (Fig. 2) - on bark of black alder, XVIII: 52, SYKO. RA. - This is a rare species in Russia. It is included in the global IUCN Red List of Threatened Species in the category Near Threatened (Randlane, 2015). Distribution in Russia: Murmansk Region (Halonen, 1996), Republic of Komi (Pystina et al., 1999, Pystina 2001; Degteva, 2019), Republic of Mari El (Bogdanov, 2015; Bogdanov \& Urbanavichus, 2008), and Sverdlovsk Region (Paukov $\&$ Teptina, 2012, 2013).

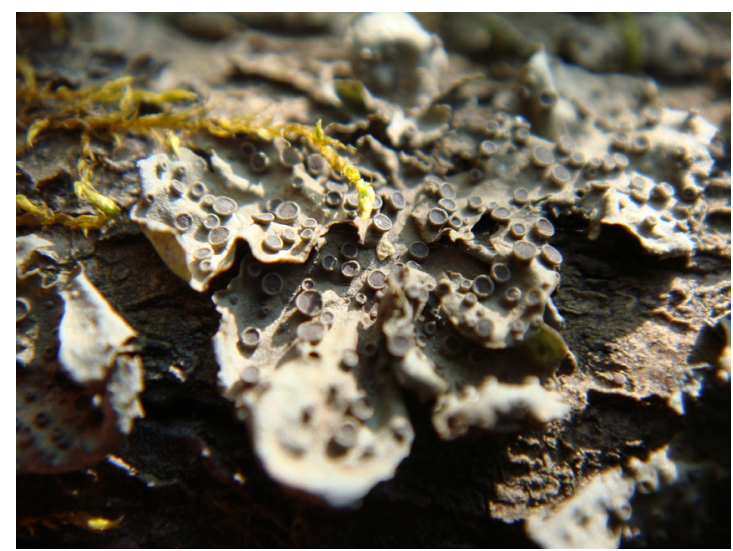

Fig. 2. Fertile thallus of Leptogium rivulare (Ach.) Mont. on bark of black alder.

\# Lichenodiplis lecanorae (Vouaux) Dyko \& D. Hawksw. - on Mycoblastus sanguinarius (thallus), IX: 42, LE 310131. - A common cosmopolitan species reported from various distantly related lichen host genera (Brackel, 2014). Previously known in Arkhangelsk Region only from its Arctic part (Nenets Autonomous Area) (Zhurbenko, 2009a). Distribution in neighboring territories: Leningrad Region (Stepanchikova et al., 2017).

\# Lichenosticta alcicorniaria (Linds.) D. Hawksw. - on Cladonia coniocraea (on the lower surface of basal squamules), X: 43, LE 310123. - A common subcosmopolitan species confined to Cladonia (Brackel, 2014; Zhurbenko \& PinoBodas, 2017). Previously known in Arkhangelsk Region only from its Arctic part (Nenets Autonomous Area; Zhurbenko \& Alstrup, 2004; Zhurbenko, 2008). Distribution in neighboring 
territories: Leningrad Region (Himelbrant et al., 2013), Murmansk Region (Zhurbenko \& Alstrup, 2004), Republic of Karelia (Fadeeva et al., 2007), Yamal-Nenets Autonomous Area (Zhurbenko, 2008), and Republic of Komi (Zhurbenko, 2004).

!\# LiCHENOSTIGMA MAURERI Hafellner - on Usnea dasypoga (thallus), XI: 44, LE 310129. - Another common cosmopolitan species that is reported from various host lichen genera (Brackel, 2014). Distribution in neighboring territories: Leningrad Region (Himelbrant et al., 2018), Republic of Karelia (Alstrup et al., 2005), Yamal-Nenets Autonomous Area (Zhurbenko, 2009b), and Republic of Komi (Zhurbenko, 2004).

! Melanelixia subaurifera (Nyl.) O. Blanco et al. - on smooth bark of alder, less often on bark of spruce, I: 9-10, 16, PZV. - A common boreal species reported from most regions of Russia (Urbanavichus, 2010). Distribution in neighboring territories: Murmansk Region (Urbanavichus et al., 2008), Leningrad Region (Kuznetsova et al., 2007a), Republic of Komi (Hermansson et al., 2006), and Republic of Karelia (Fadeeva et al., 2007).

! Melanohalea exasperata (De Not.) O. Blanco et al. - on bark of aspen, I: 2, PZV. - A common boreal species reported from most regions of Russia (Urbanavichus, 2010). Distribution in neighboring territories: Murmansk Region (Urbanavichus et al., 2008), Leningrad Region (Kuznetsova et al., 2007a), Republic of Karelia (Fadeeva et al., 2007), and Republic of Komi (Pystina, 2003).

! Micarea botryoides (Nyl.) Coppins - on roots of fallen spruce trees, III: 23, 24, PZV. - Rare in Russia. Distribution in Russia: Leningrad Region (Stepanchikova et al., 2017), Republic of Karelia (Alstrup et al., 2005, Fadeeva et al., 2007), Kaliningrad Region (Dedkov et al., 2006; Czarnota, 2007), and Republic of Dagestan (Ismailov et al., 2019).

! Micarea contexta Hedl. - on bark of dead bird cherry, I: 8; on stump of spruce, III: 25; on bark of standing dead spruce tree, III: 26, PZV. - Rare in Russia. Distribution in Russia: Republic of Karelia (Fadeeva et al., 2007), Republic of Komi (Hermansson et al., 2006), Leningrad Region (Himelbrant et al., 2018), Kamchatka Territory, and Sakhalin Region (Konoreva et al., 2019a).

! Micarea Elachista (Körb.) Coppins \& R. Sant. on stand dead spruce tree, III: 27, PZV. - A com- mon boreal species reported from most regions of Russia (Urbanavichus, 2010). Distribution in neighboring territories: Republic of Karelia (Fadeeva et al., 2007), Republic of Komi (Pystina, 2001; Hermansson et al., 2006), Leningrad Region (Himelbrant et al., 2018), and Murmansk Region (Urbanavichus et al., 2008).

! Micarea fallax Launis \& Myllys - on bark of fallen spruce tree, I: 7; on stump of spruce, III: 34, PZV. - New to Russia. Distribution worldwide: Finland, Belarus, Czech Republic, Scotland, Sweden and Germany (Launis et al., 2019a). Morphologically, Micarea fallax is very similar to M. prasina s. str. and M. laeta; it differs from $M$. prasina s. str., which also produces micareic acid, mainly by crystals in hymenia (pol+), poorly developed thallus (if growing on wood) and bark preference. The secondary metabolites are important for the separation of $M$. fallax and M. laeta: $M$. fallax produces micareic acid, whereas $M$. laeta produces methoxymicareic acid (Launis et al., 2019a).

MicAREA Globulosella (Nyl.) Coppins - on roots of fallen dead birch tree, III: 28, 34, PZV. - This species is widespread in the world, and sporadically found in Russia (Czarnota, 2007; Urbanavichus, 2010), but is often overlooked by researchers. Previously known in Arkhangelsk Region only from Onezhsky District (Tarasova et al., 2019). The specimens contain gyrophoric acid.

! Micarea hedlundi Coppins - on stump of spruce, III: 24, 34; on bark of willow, III: 34, PZV. - A common boreal species reported from most regions of Russia. Distribution in neighboring territories: Leningrad Region (Stepanchikova et al., 2011), Tver Region (Notov et al., 2016), and Republic of Komi (Pystina, 2001; Hermansson et al., 2006). The specimens contain no substances.

! MicAREA LAETA Launis \& Myllys - on bark of dead bird cherry, I: 8, PZV. - New to the European part of Russia. Distribution worldwide: Russia - Sakhalin Region (Konoreva et al. 2019a), Finland, Sweden (Launis et al., 2019b), Austria, Germany, Great Britain and North America (Konoreva et al., 2019a). Morphologically, Micarea laeta is very similar to $M$. byssacea, $M$. microareolata and $M$. fallax; all these species have crystals (pol+) in hymenium and thallus. Micarea laeta never produces the Sedifolia-grey pigment in apothecia (while $M$. byssacea, on the 
contrary, usually produces this pigment); contains methoxymicareic acid (whereas $M$. fallax contains micareic acid) (Launis et al., 2019b); ascospores 3-4 $\mu \mathrm{m}$ wide and goniocysts usually coalescing to form continuous crust or larger granules (while $M$. microareolata has narrower spores (2-3 $\mu \mathrm{m}$ wide) and an areolate thallus) (Launis et al., 2019b).

! MicAREA PRASINA Fr. s. str. - on stump of spruce, I: $5,17,21$; III: $25,31,32$, on bark of birch, III: 29, 30, PZV. - A common subcosmopolitan species, known in Russia from most regions as Micarea prasina s. lat. and needs to be revised. Distribution in neighboring territories (confirmed data about $M$. prasina s. str.): Leningrad Region (Konoreva \& Chesnokov, 2017), Republic of Karelia (Fadeeva et al., 2007), Murmansk Region (Urbanavichus et al., 2008), and Republic of Komi (Hermansson et al., 2006). The specimens contain micareic acid. Crystals (pol+) are present in the epihymenium.

! MicAREA MiCROAREOLATA Launis et al. - on bark of stand dead spruce tree, I: 8, PZV. - Rare in Russia and in the world. Distribution worldwide: Russia - Leningrad Region and Sakhalin Region (Konoreva et al., 2019a), Finland, Sweden (Launis et al., 2019b), Germany, Czech Republic and USA (Konoreva et al., 2019a). The examined material is not sufficient for chromatography, but the morphology of the sample is consistent with the description (Launis et al., 2019b): thallus effuse, pale olive green, thin, form convex to subglobose small areolae, apothecia adnate, ascospores 0-1-septate, 7.5-10 × 2-3 $\mu \mathrm{m}$. Crystals (pol+) present in the hymenium and thallus.

Micarea peliocarpa (Anzi) Coppins \& R. Sant. - on roots of fallen spruce, III: 33, PZV. - A cosmopolitan species. Previously known only from Onezhsky District of Arkhangelsk Region (Tarasova et al., 2019).

! Micarea pusilla Launis et al. - on stump of spruce, III: 34; on bark of dead bird cherry, I: 8, PZV. - New to the European part of Russia. Distribution worldwide: Russia - Republic of Dagestan, Finland, and Czech Republic (Launis et al., 2019a). Micarea pusilla is characterized by small, numerous and crowded whitish apothecia, olive green warted-granular or membranous thallus, and it contains methoxymicareic acid, while Sedifolia-grey pigment and crystals (pol-) are absent in the apothecia section and thallus (Launis et al., 2019a).
! Micarea tomentosa Czarnota \& Coppins - on bark of fallen spruce tree, I: 7, PZV. - This is a rare species in Russia. Distribution in Russia: Moscow Region (Muchnik et al., 2019), Republic of Mordovia (Urbanavichene \& Urbanavichus, 2017), Yakutia, Trans-Baikal Territory (Konoreva et al., 2018), and Kamchatka Territory (Konoreva et al., 2019a).

!+ Microcalicium ahlneri Tibell. - on bark on trunks and branches of spruce, I: 7, 12, 15-17, $\mathrm{PZV}$; on lignum of standing dead pine, XIX: 53, SYKO. - A common boreal species reported from most regions of Russia (Urbanavichus, 2010). Distribution in neighboring territories: Leningrad Region (Stepanchikova et al., 2010, 2013), Republic of Karelia (Fadeeva et al., 2007), Republic of Komi (Hermansson et al., 2006), and Tver Region (Notov et al., 2011).

! Nephroma helveticum Ach. (Fig. 3) - on bark of black alder, XXII: 58, SYKO. RA. - Distribution in neighboring territories: Republic of Karelia (Fadeeva et al., 2007), Republic of Komi (Degteva, 2019), Murmansk Region (Konstantinova et al., 2014), and Vologda Region (Konechnaya $\&$ Suslova, 2004).

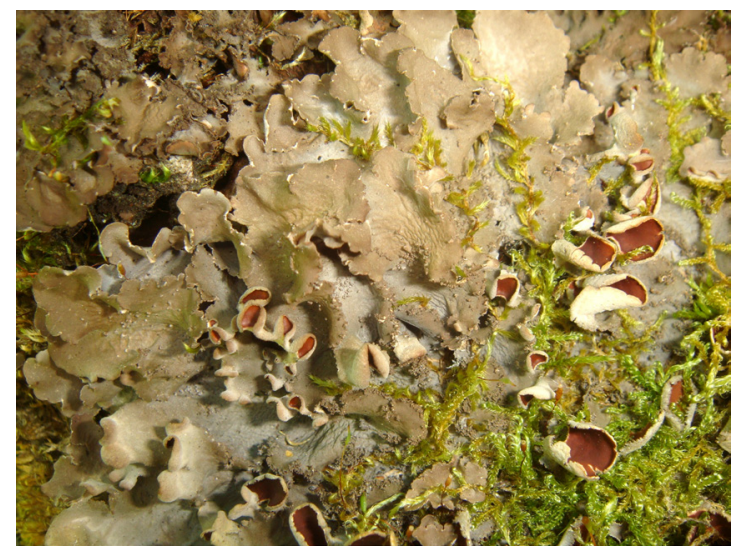

Fig. 3. Fertile thallus of Nephroma helveticum Ach. on bark of black alder.

! NEPHROMOPSIS LAURERI (Kremp.) Kurok. - on bark of spruce, birch, rarely on fir, XXIII: 60-66, SYKO, RA. - Distribution in neighboring territories: Republic of Karelia (Fadeeva et al., 2007), Republic of Komi (Degteva, 2019), and Kirov Region (Baranova et al., 2014).

\#! Nigropuncta Rugulosa D. Hawksw. (Fig. 4) - on Bellemerea (thallus), XII: 45, LE 309452. - This 
species was previously considered as a conidial lichen (Hawksworth \& Poelt, 1986), but it is a lichenicolous fungus confined to Bellemerea (Diederich et al., 2018). We have observed in our material hyaline, bacilliform microconidia, not mentioned in the protologue (Fig. 4D; Hawksworth, 1981). The species is known from scattered finds in the Holarctic (Hawksworth \& Poelt, 1986; Wirth, 1992; Hafellner, 1993; Alstrup \& Elvebakk, 1996; Alstrup \& Cole, 1998; Santesson et al., 2004; Hafellner \& John, 2006; Alstrup et al., 2009; Etayo, 2010) and was also reported from New Zealand (Hafellner \& Mayrhofer, 2007). It was previously known in Russia by an unpublished record from the Republic of Komi [Paga River, about $35 \mathrm{~km}$ SNE of Sivaja Maska, $66^{\circ} 22^{\prime} 00.01^{\prime \prime} \mathrm{N}, 62^{\circ} 52^{\prime} 00.01^{\prime \prime} \mathrm{E}$, on Bellemerea cinereorufescens growing on rocks in tundra, 26.06.2007, Janolof Hermansson, 15610a, UPS: BOT: F-165224].

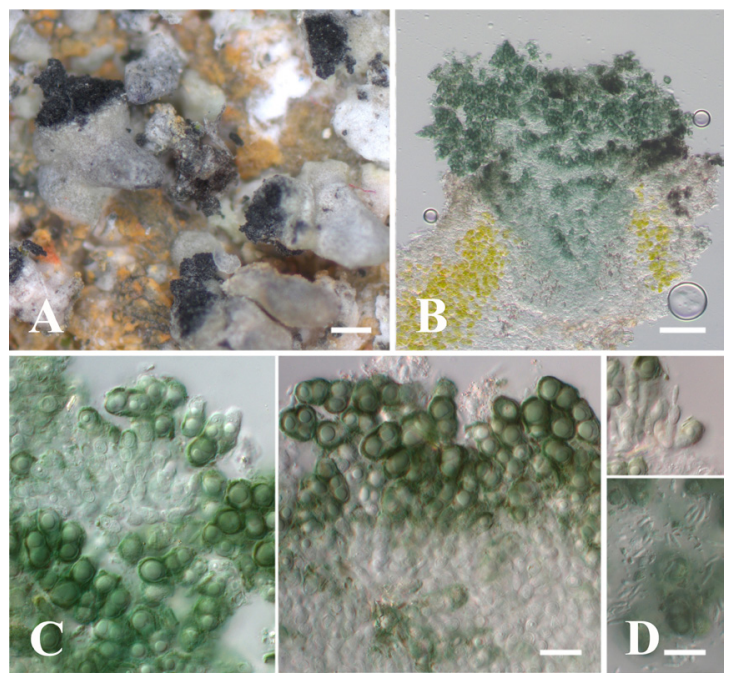

Fig. 4. Nigropuncta rugulosa D. Hawksw. (LE 309452). A - habitus of conidiomata on the thallus of Bellemerea; B - conidioma in cross section in water; $\mathrm{C}$ - conidiomata in cross section in $\mathrm{K}$, note conidiophores, conidiogenous cells and conidia; $\mathrm{D}-$ microconidia in $\mathrm{K}$ (above) and water (below). Scales: $A=200 \mu \mathrm{m} ; \mathrm{B}=50$ $\mu \mathrm{m} ; \mathrm{C}, \mathrm{D}=10 \mu \mathrm{m}$.

Peltigera elisabethae Gyeln. - on trunk base of birch, XXII: 59, SYKO, RA. - This species was formerly known in Arkhangelsk Region from its Arctic part (Franz Josef Land; Konoreva et al., 2019b), and from Pinezhsky District (Zeleznye
Vorota Reserve, Stanovy Log, 6446’36.98”N, $43^{\circ} 05^{\prime} 22.5^{\prime \prime} \mathrm{E}$, on gypsum in sparse lichen-feathermoss pine forests on the karst ravine, 2008, leg. LP, det. E. Kuznetsova \& D. Himelbrant, Herbarium of Pinezhsky Reserve; unpublished record).

! Pertusaria coccodes (Ach.) Nyl. - on bark of spruce and aspen, I: 1, 17-19, PZV. - This species is an indicator of old-growth forests (Andersson et al., 2009) and is reported from most regions of Russia (Urbanavichus, 2010; Davydov \& Printzen, 2012). Distribution in neighboring territories: Murmansk Region (Urbanavichus et al., 2008), Leningrad Region (Kuznetsova et al., 2007a), Republic of Karelia (Fadeeva et al., 2007), and Republic of Komi (Pystina, 2003).

!+ Phaeocalicium praecedens (Nyl.) A. F. W. Schmidt - on bark of aspen, I: 2, PZV. - A common boreal species reported from most regions of Russia (Urbanavichus, 2010). Distribution in neighboring territories: Leningrad Region (Stepanchikova et al., 2010, 2013), and Republic of Komi (Hermansson et al., 1998).

! Protothelenella leucothelia (Nyl.) H. Mayrhofer \& Poelt (Fig. 5) - on stones with thin soil layer, II: 22, PZV, RA. - A rare arctic-alpine species. Distribution in neighboring territories: Murmansk Region (Urbanavichus et al., 2008), and Republic of Komi (Hermansson et al., 2006).

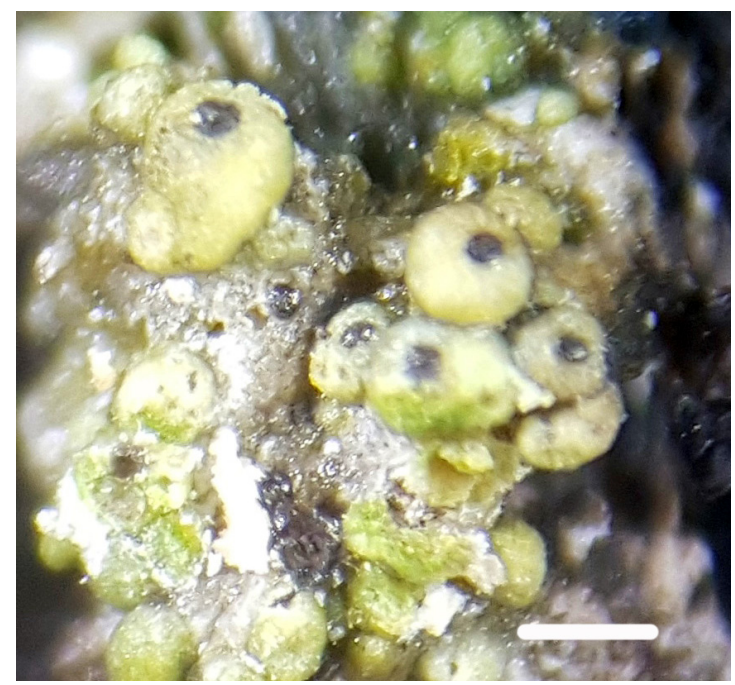

Fig. 5. Fertile thallus of Protothelenella leucothelia (Nyl.) H. Mayrhofer \& Poelt on stone with thin soil layer. Scale: $0.5 \mathrm{~mm}$. 
\# Pseudopyrenidium tartaricola (Linds.) Nav.Ros., Zhurb. \& Cl. Roux - on Ochrolechia mahluensis (thallus) growing on spruce twigs, XII: 46, LE 310130. - This species was previously known from scattered finds throughout Holartic, mainly from the Arctic and alpine habitats, growing on Ochrolechia (Alstrup \& Hawksworth, 1990; Alstrup \& Elvebakk, 1996; Santesson et al., 2004; Navarro-Rosinés et al., 2010; Brackel, 2014). It was formerly known in Arkhangelsk Region only from its Arctic part, viz. Franz Josef Land and Nenets Autonomous Area (Zhurbenko \& Santesson, 1996; NavarroRosinés et al., 2010). Distribution in neighboring territories: Murmansk Region (Navarro-Rosinés et al., 2010), and Yamal-Nenets Autonomous Area (Zhurbenko \& Zhdanov, 2013).

! Psoroglaena dictyospora (Orange) H. Harada - on dead wood, I: 20, PZV. - Distribution in neighboring territories: Tver Region (Notov et al., 2011), Leningrad Region (Himelbrant et al., 2015), Pskov Region (Istomina et al., 2018), and Republic of Komi (Hermansson et al., 2006).

RAmalina obTUSATA (Arnold) Bitter - on standing dead fir, XVII: 51, SYKO, RA. - This species is known from most regions of Russia (Urbanavichus, 2010). Formerly known in Arkhangelsk Region only from Onezhsky District (Fadeeva, 2006).

!\# SPIRographa fusisporella (Nyl.) Zahlbr. on Xylographa vitiligo (thallus), XIII: 47, LE 310127. - This species was reported from both hemispheres growing on various distantly related lichen host genera (Brackel, 2014). It was previously known in Russia from Komi Republic, Murmansk Region, and Magadan Region (Zhurbenko, 2009a; Zhurbenko et al., 2012; Zhurbenko \& Zheludeva, 2015).

STEINIA GEOPHANA (Nyl.) Stein - on bark of aspen and dead spruce, I: 2, IV: 36, PZV. - This species was formerly known in Arkhangelsk Region only from its Arctic part (Franz Josef Land; Konoreva et al., 2019b).

!+ Stenocybe major Nyl. - on bark of fir, XX: 55, SYKO. - Widely distributed in the Holarctic (Titov, 2006). Distribution in neighboring territories: Republic of Komi (Pystina, 2003), and Kostroma Region (Urbanavichene \& Urbanavichus, 2019).

!\# Tremella hypogymniae Diederich \& M. S. Christ. - on Hypogymnia physodes (thallus),
XIV: 48, LE 310133. - This species is widely distributed in the Holarctic growing on Hypogymnia (Diederich, 1996; Brackel, 2014). Distribution in neighboring territories: Leningrad Region (Himelbrant et al., 2018), Murmansk Region (Zhurbenko \& Zhdanov, 2013), Republic of Karelia (Alstrup et al., 2005), and Republic of Komi (Alstrup, 2014).

Tuckermannopsis ciliaris (Ach.) Gyeln. - on branches of old birches, XV: 50, PZV, RA. - This species was formerly known in Arkhangelsk Region from Pinezhsky Reserve in Pinezhsky District (Puchnina et al., 2000). Distribution in neighboring territories: Murmansk Region (Urbanavichus et al., 2008), Leningrad Region (Kuznetsova et al., 2007a), Republic of Karelia (Fadeeva et al., 2007), and Republic of Komi (Pystina, 2003).

\section{DISCUSSION}

In total, 31 species of lichens, 12 lichenicolous and 5 non-lichenized fungi are listed. Among these, 35 species are recorded for the first time for the Arkhangelsk Region and 7 species (Endococcus propinquus, Epicladonia sandstedei, Lichenosticta alcicorniaria, Lichenodiplis lecanorae, Peltigera elisabethae, Pseudopyrenidium tartaricola and Steinia geophana) are new for its mainland area (i.e. the species have earlier been recorded only from arctic islands). Micarea fallax is new to Russia, Micarea laeta and M. pusilla are new to its European part. The second finding of Nicropuncta rugulosa in Russia is documented; microconidia are first observed in this species. Ten species are included in the new edition of the Red Data Book of Arkhangelsk Region (Anufriev et al., 2020): Chaenotheca gracillima, C. sphaerocephala, C. phaeocephala, Leptogium rivulare, Nephroma helveticum, Nephromopsis laureri, Peltigera elisabethae, Protothelenella leucothelia, Ramalina obtusata and Tuckermannopsis ciliaris. Nephromopsis laureri which is included also in the Red Data Book of Russian Federation (Bardunov \& Novikov, 2008), and Leptogium rivulare which has been assessed as Near Threatened in the IUCN Red List (Randlane, 2015) are first documented for Arkhangelsk Region.

\section{ACKNOWLEDGEMENTS}

We would like to express our gratitude to the staff of Vodlozersky National Park (Viktor Ma- 
montov, Maria Shreders, Vasily Ruchyovskih and Sergei Zakutin) for the help in organization of expeditions and to WWF-Russia (Arkhangelsk department) for organization and support with expedition to the upper reaches of Njukhcha River. We are grateful to Gennady Urbanavichus for the identification of Protothelenella leucothelia and information regarding species distribution; to Ilya Kucherov and Stanislav Kutenkov for consultations regarding the types of communities; to Natalia Burova, Elena Churakova and Liudmila Puchnina for collecting lichen specimens. We are grateful to the reviewers for valuable corrections and recommendations, which have improved the quality of our work.

The study was supported by RFBR (project number 20-04-00473), Ministry of Education and Science of the Russian Federation; additional support was provided by the Avrorin PolarAlpine Botanical Garden-Institute of the Russian Academy of Sciences (institutional project No AAAA-A18-118050490088-0, to L. Konoreva), the Komarov Botanical Institute of the Russian Academy of Sciences (institutional project No AAAA-A19-119020690077-4, to S. Chesnokov), the N. Laverov Federal Center for Integrated Arctic Research of the Russian Academy of Sciences (project AAAA-A17-117122990042-2, to A. Valekzhanin), the Institute of Biology of Komi Science Centre of the Ural Branch of the Russian Academy of Sciences (project no. A19119011790022-1, to TP \& NS), and the Russian Foundation for Basic Research, RFBR (grant no. 18-05-60093, to L. Konoreva and S. Chesnokov).

The studies of M. P. Zhurbenko were carried out within the framework of the research project of the V. L. Komarov Botanical Institute of the Russian Academy of Sciences "Biodiversity, ecology and structural and functional features of fungi and fungus-like protists, AAAA-A19-119020890079-6" and the Basic Research Program of the Russian Academy of Sciences I.2.41, the project "Biological diversity and dynamics of the plant world of Russia" using equipment of its Core Facility Center "Cell and Molecular Technologies in Plant Science».

\section{REFERENCES}

Alstrup, V. 2014. Additions to the lichens and lichenicolous fungi of the Syktyvkar area, Komi Republic, Russia. Graphis Scripta 26(1-2): 40-41.
Alstrup, V. \& Cole, M. S. 1998. Lichenicolous fungi of British Columbia. Bryologist 101: 221-229. https://doi.org/10.2307/3244200

Alstrup, V. \& Elvebakk, A. 1996. Part 5. Fungi III. Lichenicolous fungi. In: Elvebakk, A. \& Prestrud, P. (eds). A catalogue of Svalbard plants, fungi, algae and cyanobacteria. Norsk Polar Institutt Skrifter 198: 261-270.

Alstrup, V. \& Hawksworth, D. L. 1990. The lichenicolous fungi of Greenland. Meddelelser om Grønland, Bioscience 31: 1-90.

Alstrup, V., Kocourková, J., Kukwa, M., Motiejūnaitė, J., Brackel, W. V. \& Suija, A. 2009. The lichens and lichenicolous fungi of South Greenland. Folia Cryptogamica Estonica 46: 1-24.

Alstrup, V., Zavarzin, A. A., Kocourcová, J., Kravchenko, A. V., Fadeeva, M. A. \& Shiefelbein, U. 2005. Lichens and lichenicolous fungi found in Northern Ladoga Area (Republic of Karelia) during the international fieldtrip in August 2004, prior to the fifth congress of International Lichenological Association: Preliminary Report. Proceedings of $\mathrm{Ka}$ relian Research Center of the Russian Academy of Sciences 5: 3-15. (in Russian, English summary).

Andersson, L., Alexeeva, N. \& Kuznetsova, E. (eds). 2009. Survey of biologically valuable forests in North-Western European Russia. Vol. 2. Identification manual of species to be used during survey at stand level. St. Petersburg. 258 pp. (in Russian).

Anufriev, V. V., Bespalaya, Yu. V., Bolotov, I. N., Ezhov, O. N., Mamontov, V. N., Mizin, I. A., Potapov, G. S., Puchnina, L. V., Pystina, T. N., Svetochev, V. N., Chemeris, E. V. \& Churakova, E. Yu. (eds). 2020. Red Data Book of the Arkhangelsk region. Arkhangelsk. 478 pp. (in Russian).

Baranova, O. G., Lachokhi, E. P., Ryabova, V. M., Sotnikova, V. N., Tarasova, E. M. \& Tselishcheva, L. G. (eds). 2014. Red Data Book of the Kirov region: animals, plants, mushrooms. Kirov, Kirov Regional Printing House. 336 pp. (in Russian).

Bardunov, L. V. \& Novikov, V. S. (eds). 2008. Red Data Book of the Russian Federation. Plants and Fungi. Moscow, KMK Scientific Partnership. 885 pp. (in Russian).

Bogdanov, G. A. 2015. A list of lichens for the "Bolshaya Kokshaga" Nature Reserve. Scientific Papers of the State Nature Reserve "Bolshaya Kokshaga" 7: 206-244. (in Russian).

Bogdanov, G. A. \& Urbanavichus, G. P. 2008. Lichen species new and rare to Russia from the Republic of Marii El. Botanicheskii Zhurnal 93(6): 944-950. (in Russian, English summary).

Brackel, W. V. 2014. Kommentierter Katalog der flechtenbewohnenden Pilze Bayerns. Bibliotheca Lichenologica 109: 1-476.

Brenner, M. 1885. Bidrag till kännedomen om Finska Vikens övegetation. IV. Hoglands lafvar (Beiträge zur Kenntnis der Inselflora des Finnischen Busens IV. Hoglands Flechten) Meddelanden af Societas pro Fauna et Flora Fennica 12: 1-143. 
Czarnota, P. 2007. The lichen genus Micarea (Lecanorales, Ascomycota) in Poland. Polish Botanical Studies 23: 1-199.

Davydov, E. A. \& Printzen, C. 2012. Rare and noteworthy boreal lichens from the Altai Mountains (South Siberia, Russia). Bryologist 115(1): 61-73. https://doi.org/10.1639/0007-2745.115.1.61

Dedkov, V. P., Andreev, M. P. \& Petrenko, D. E. 2006. An annotated list of lichens and fungi lichenicolous Kaliningrad region. In: Dedkov, V. P. \& Gubaryova I. Yu. (eds). Biodiversity of the Kaliningrad region. Part 1. Fungi, lichens, plunders, horsetails, ferns. Kaliningrad, Publishing House of the Baltic Federal University named after Immanuel Kant. Pp. 79-178. (in Russian).

Degteva, S. V. (ed.). 2019. Red Data Book of the Komi Republic. Syktyvkar. 768 pp. (in Russian).

Diederich, P. 1996. The lichenicolous heterobasidiomycetes. Bibliotheca Lichenologica 61: 1-198.

Diederich, P., Lawrey, J. D. \& Ertz, D. 2018. The 2018 classification and checklist of lichenicolous fungi, with 2000 non-lichenized, obligately lichenicolous taxa. Bryologist 121: 340-425. https://doi. org/10.1639/0007-2745-121.3.340

Etayo, J. 2010. Liquenes y hongosliquenícolas de Aragón. Guineana 16: 1-501. (in French).

Fadeeva, M. A., 2006. Lichens. - In: Nature and historical and cultural heritage of Kozhozerye. Arkhangelsk, pp. 75-102. (in Russian).

Fadeeva, M. A., Golubkova, N. S., Vitikainen, O. \& Ahti, T. 2007. Conspectus of lichens and lichenicolous fungi of the Republic of Karelia. Petrozavodsk, Karelian Research Center of the Russian Academy of Sciences. 194 pp. (in Russian, English summary).

Gruzdev, B. I., Degteva, S. V., Dulin, M. V., Zheleznova, G. V., Kanev, V. A., Korolev, A. N., Kosolapov, D. A., Kochanov, S. K., Kustysheva, A. A., Liskevich, O. N., Martynenko, V. A., Petrov, A. N., Poletaeva, I. I., Pystina, T. N., Semenova, N. A., Teteryuk, L. V. \& Shubin, T. P. 2005. Protected natural complexes of the Vychegod-Mezensky plain. - In: Degteva, S.V. (ed.). Biological variety of specially protected natural territories of the Komi Republic. Vol. 2. Syktyvkar. 172 pp. (in Russian).

Hafellner, J. \& Mayrhofer, H. 2007. A contribution to the knowledge of lichenicolous fungi and lichens occurring in New Zealand. Bibliotheca Lichenologica 95: 225-266.

Hafellner, J. 1993. Über Funde von lichenicolen Pilzen und Flechten im südlichen Norwegen. Herzogia 9: 749-768.

Hafellner, J. \& John, V. 2006. Über Funde lichenicoler nicht-lichenisierter Pilze in der Türkei, miteiner Synopsis der bisher im Land nachgewiesenen Taxa. Herzogia 19: 155-176.

Halonen, P. 1996. Lichens of the former Kutsa Nature Reserve. Oulanka Reports 16: 63-68.

Hawksworth, D. L. \& Poelt, J. 1986. Five additional genera of conidial lichen-forming fungi from
Europe. Plant Systematics and Evolution 154: 195-211. https://doi.org/10.1007/BF00990123

Hawksworth, D. L. 1981. The lichenicolous coelomycetes. Bulletin of the British Museum (Natural History), Botany Series 9: 1-98.

Hermansson, J., Pystina, N. T. \& Kudrejasheva, D. I. 1998. Previous list of lichens of the Republic of Komi. Syktyvkar. 136 pp. (in Russian).

Hermansson, J., Pystina, T. N., Ove-Larsson, B. \& Zhurbenko, M. P. 2006. Lichens and lichenicolous fungi of the Pechoro-Ilychsky Nature Reserve. Flora i fauna zapovednikov 109: 1-79. (in Russian).

Himelbrant, D. E. 2016. The lichens and allied fungi from the Leningrad Region and Saint Petersburg in the lichen herbarium of the University of Tartu. Folia Cryptogamica Estonica 53: 35-42. https:// doi.org/10.12697/fce.2016.53.05

Himelbrant, D. E., Motiejūnaite, J., Pykälä, J., Schiefelbein, U. \& Stepanchikova I. S. 2013. New records of lichens and allied fungi from the Leningrad Region, Russia. IV. Folia Cryptogamica Estonica 50: 23-31. https://doi.org/10.12697/fce.2013.50.04

Himelbrant, D. E., Stepanchikova, I. S. \& Kuznetsova, E. S. 2009. Lichens of some shrubs and subshrubs of the Kamchatka Peninsula. Novitates Systematicae Plantarum non Vascularium 43: 150-171. (in Russian, English summary).

Himelbrant, D. E., Stepanchikova, I. S., Kuznetsova, E. S., Motiejūnaitė, J. \& Konoreva, L. A. 2018. Konevets Island (Leningrad Region, Russia) - a historical refuge of lichen diversity in Lake Ladoga. Folia Cryptogamica Estonica 55: 51-78. https:// doi.org/10.12697/fce.2018.55.07

Himelbrant, D. E., Stepanchikova, I. S., Motiejūnaitè, J., Gagarina, L. V. \& Dyomina, A. V. 2016. New records of lichens and allied fungi from the Leningrad Region, Russia. VII. Folia Cryptogamica Estonica 53: 25-34. https://doi.org/10.12697/ fce.2016.53.04

Himelbrant, D. E., Stepanchikova, I. S., Motiejūnaitė, J., Vondrak, J., Tagirdzhanova, G. M., Gagarina, L. V. \& Kuznetsova, E. S. 2015. New records of lichens and allied fungi from the Leningrad Region, Russia. VI. Folia Cryptogamica Estonica 52: 21-28. https://doi.org/10.12697/fce.2015.52.03

Ismailov, A. B., Vondrák, J. \& Urbanavichus, G. P. 2019. The Express-Method of Estimation of Epiphytic Lichens Diversity. Russian Journal of Forest Science 4: 294-303 (in Russian, English summary). https://doi.org/10.1134/ S0024114819030045

Istomina, N. B., Likhacheva, O. V., Stepanchikova, I. S., Kuznetsova, E. S. \& Himelbrant, D. E. 2018. New and rare lichens and allied fungi from the Pskov Region, Russia. Folia Cryptogamica Estonica 55: 21-31. https://doi.org/10.12697/ fce.2018.55.04

Ivanter, E. V. \& Kuznetsov, O. L. (eds). 2007. Red Data Book of Republic Karelia. Petrozavodsk. 368 pp. (in Russian). 
Konechnaya, G. Yu., Suslova, T. A. (eds). 2004. Red Data Book of Vologda Region. Vol. 2. Plant and Fungi. Vologda. 360 pp. (in Russian).

Konoreva, L. A. \& Chesnokov, S. V. 2017. Distribution of some species of the genus Micarea Fr. in Russia. In: Notov, A. A. (ed.). Biodiversity: approaches of study and conservation: Proceeding of the International Scientific Conference dedicated to $100^{\text {th }}$ anniversary of the Department of Botany of Tver State University (Tver, 8-11 November 2017). Tver: Tver State University. Pp. 169-172. (in Russian).

Konoreva, L. A., Chesnokov, S. V. \& Poryadina, L. N. 2018. Lichen genus Micarea Fr. in Asian Part of Russia. Sakha Republic (Yakutia) and TransBaikal Territory. Turczaninowia 21: 102-120. (in Russian, English summary). https://doi. org/10.14258/turczaninowia.21.3.14

Konoreva, L., Chesnokov, S., Kuznetsova, E. \& Stepanchikova, I. 2019a. Remarkable records of Micarea from the Russian Far East and significant extension of Micarea laeta and M. microareolata range. Botanica 25(2): 186-201. https://doi. org/10.2478/botlit-2019-0020

Konoreva, L. A., Kholod, S. S., Chesnokov, S. V. \& Zhurbenko, M. P. 2019b. Lichens of Franz Josef Land archipelago. Polish Polar Research 40(2): 9-170. https: / /doi.org/ 10.24425/ppr.2019.128372

Konstantinova, N. A., Koryakin, A. S., Makarova, O. A. \& Bianki, V. V. (eds). 2014. Red Data Book of the Murmansk Region. Second edition. Kemerovo, Asia-print. 584 pp. (in Russian).

Kuznetsova, E., Ahti, T. \& Himelbrant, D. 2007a. Lichens and allied fungi of the Eastern Leningrad Region. Norrlinia 16: 1-62.

Kuznetsova, E., Himelbrant, D. \& Titov, A. 2007b. Lichens of Vepssky Forest Protected Area (Eastern Leningrad Region, Russia) with special emphasis on the indicator species of habitats with long ecological continuity. Botanica Lithuanica 13(3): 171-179.

Kuznetsova, E. S. \& Skazina, M. A. 2010. On the study of lichens in the Kostroma region. Novitates Systematicae Plantarum non Vascularium 44: 200-209. (in Russian, English summary).

Launis, A., Malíček, J., Svensson, M., Tsurykau, A., Sérusiaux, E. \& Myllys L. 2019a. Sharpening species boundaries in the Micarea prasina group, with a new circumscription of the type species $M$. prasina. Mycologia 111(4): 574-592. https:/ / doi. org/10.1080/00275514.2019.1603044

Launis, A., Pykälä, J., van den Boom, P., Sérusiaux, E. \& Myllys, L. 2019b. Four new epiphytic species in the Micarea prasina group from Europe. Lichenologist 51: 7-25. https://doi.org/10.1017/ S0024282918000555

Lebedeva, M. Yu. 2005. Epiphytic lichens on spruce in the north-western part of Ladoga landscape area (Leningrad Region). Novitates Systematicae Plantarum Non Vascularum 39: 203-212. (in Russian).
Lynge, B. 1928. Lichens from Novaya Zemlya (exclusive of Acarospora and Lecanora). Report of the Scientific Result or the Norwegian Expedition to the Novaya Zemlya 1921 43: 1-299.

Muchnik, E., Konoreva, L., Chesnokov, S., Paukov, A., Tsurykau, A. \& Gerasimova, J. 2019. New and otherwise noteworthy records of lichenized and lichenicolous fungi from central European Russia. Herzogia 32: 111-126. https://doi. org/10.13158/heia.32.1.2019.111

Navarro-Rosinés, P., Zhurbenko, M. P. \& Roux, C. 2010. Pseudopyrenidium nova genro por inkludi Weddellomyces tartaricola (nelikeniĝinta fungo likenloĝa, Ascomycota). Bulletin de la Société linnéenne de Provence 61: 129-140. (in French).

Nordin, A., Moberg, R., Tønsberg, T., Vitikainen, O., Dalsätt, Å., Myrdal, M., Snitting, D. \& Ekman, S. 2011. Santesson's Checklist of Fennoscandian Lichen-forming and Lichenicolous Fungi. http: / / 130.238.83.220/santesson/home.php (Accessed 25 March 2019).

Notov, A. A., Himelbrant, D. E. \& Urbanavichus, G. P. 2011. The list of lichens and allied fungi of Tver Region. Tver. 124 pp. (in Russian).

Notov, A. A., Himelbrant, D. E. \& Stepanchikova, I. S. 2019. New records of lichens and lichenicolous fungi from the Tver Region. Novitates Systematicae Plantarum Non Vascularum 53(1): 157-166. https://doi.org/10.31111/nsnr/2019.53.1.157

Notov, A. A., Himelbrant, D. E., Stepanchikova, I. S. \& Volkov, V. P. 2016. Lichens of the Central Forest State Natural Biosphere Reserve. Tver State University, Tver. 332 pp. (in Russian, English summary).

Novoselov, A. P. (ed.). 2008. Red Data Book of the Arkhangelsk region. Arkhangelsk. 351 pp. (in Russian).

Orange, A., James, P. W. \& White, F. J. 2001. Microchemical methods for the identification of lichens. British Lichen Society, London. 101 pp.

Paukov, A. G. \& Teptina, A. Yu. 2013. Lichens of the natural Park “Olen'y Ruch'y” (Sverdlovsk region). Novitates Systematicae Plantarum non Vascularium 47: 237-252. (in Russian). https://doi. org/10.31111/nsnr/2013.47.237

Paukov, A. \& Teptina, A. 2012. New records of lichens from Middle Urals, Russia. Folia Cryptogamica Estonica 49: 39-43.

Puchnina, L. V., Goryachkin, S. V., Rykov, A. M. 2000. Structure and dynamics of natural components of the Pinezhsky reserve (Northern taiga of the ETR, Arkhangelsk region). Biodiversity and geodiversity in karst areas. Arkhangelsk. 267 pp. (in Russian).

Pystina, T. N. 2001. A systematic list of lichens in the lowlands of the Republic of Komi(subzones of the southern and middle taiga). Novitates Systematicae Plantarum non Vascularium 34: 176-185. (in Russian). 
Pystina, T. N. 2003. Lichens of the taiga forests of the European North-East (southern and middle taiga subzones). Ekaterinburg. 239 pp. (in Russian).

Pystina, T. N., Hermansson, J. \& Kustysheva, A. A. 1999. New data on the distribution of a rare species Leptogium rivulare (Collemataceae, Lichenes). Botanicheskii Zhurnal 84(9): 126-131. (in Russian, English summary).

Randlane, T. 2015. Leptogium rivulare. The IUCN Red List of Threatened Species 2015: e.T7 1598929A7 1599036. https: / / doi.org/ 10.2305/IUCN.UK.2015-4.RLTS.T71598929A715 99036.en

Santesson, R., Moberg, R., Nordin, A., Tønsberg, T. \& Vitikainen, O. 2004. Lichen-forming and lichenicolous fungi of Fennoscandia. Museum of Evolution, Uppsala University, Uppsala. 359 pp.

Sorokina, I. A., Stepanchikova, I. S., Himelbrant, D. E., Liksakova, N. S., Spirin, V. A., Kushnevskaya, E. V., Gagarina, L. V. \& Efimov, P. G. 2017. Brief essays of three planned protected areas of the East of the Leningrad region. Botanicheskii Zhurnal 102 (9): 1270-1289 (in Russian, English summary).

Stepanchikova, I. S., Andreev, M. P., Himelbrant, D. E., Motiejūnaitė, J., Schiefelbein, U., Konoreva, L. A. \& Ahti, T. 2017. The lichens of Bolshoy Tuters Island (Tytärsaari), Leningrad Region, Russia. Folia Cryptogamica Estonica 54: 95-116. https:// doi.org/10.12697/fce.2017.54.14

Stepanchikova, I. S., Himelbrant, D. E., Kukwa, M. \& Kuznetsova, E. S. 2011. New records of lichens and allied fungi from the Leningrad Region, Russia. II. Folia Cryptogamica Estonica 48: 85-94.

Stepanchikova, I. S., Kukwa, M., Kuznetsova, E. S., Motiejūnaiteé, J. \& Himelbrant, D. E. 2010. New records of lichens and allied fungi from the Leningrad Region, Russia. Folia Cryptogamica Estonica 47: 77-84.

Stepanchikova, I. S., Tagirdzhanova, G. M. \& Himelbrant, D. E. 2013. The lichens and allied fungi of the Smorodinka River valley (Leningrad region). Novitates Systematicae Plantarium Non Vascularum 47: 262-278. https://doi.org/10.31111/ nsnr/2013.47.262

Tarasova, V. N., Pystina, T. N., Androsova, V. I., Sonina, A. V., Valekzhanin, A. A. \& Konoreva, L. A. 2019. New records of lichens and allied fungi from Vodlozersky National Park within Arkhangelsk Region (NW Russia). Folia Cryptogamica Estonica 56: 87-98. https://doi.org/10.12697/ fce.2019.56.09

Tarasova, V., Sonina, A., Androsova, V. \& Stepanchikova, I. 2016. The lichens of forest rocky communities of the hill Muroigora (Arkhangelsk Region, Northwest Russia). Folia Cryptogamica Estonica 53: 111-121. https://doi.org/10.12697/ fce. 2016.53 .13

Tarasova V. N., Sonina A. V., Androsova V. I. \& Stepanchikova I. S. 2015. The lichens of forest rocky communities of mountain Olovgora
(Arkhangelsk Region, Northwest Russia). Folia Cryptogamica Estonica 52: 51-62. https://doi. org/ 10.12697/fce.2015.52.07

Titov, A. N. 2006. Mycocaliciaceae fungi of the Holarctic. Moscow. 296 pp. (in Russian).

Triebel, D. 1989. Lecideicole Ascomyceten. Eine Revision der obligat lichenicolen Ascomyceten auf lecideoiden Flechten. Bibliotheca Lichenologica 35: 1-278.

Urbanavichene, I. N. \& Urbanavichus, G. P. 2017. Micarea tomentosa (Pilocarpaceae, lichenized Ascomycota) new to Russia from the Republic of Mordovia. Turczaninowia 20: 30-34. https: / / doi. org/10.14258/turczaninowia.20.1.2

Urbanavichene, I. N. \& Urbanavichus, G. P. 2019. New records of lichens and allied fungi from the Kostroma Region, Russia. Folia Cryptogamica Estonica 56: 53-62. https://doi.org/10.12697/ fce.2019.56.06

Urbanavichus, G., Ahti, T. \& Urbanavichene, I. 2008. Catalogue of lichens and allied fungi of Murmansk Region, Russia. Norrlinia 17: 1-80.

Urbanavichus, G. P. 2010. A checklist of the lichen flora of Russia. St. Petersburg. 194 pp. (in Russian).

Urbanavichus, G. \& Urbanavichene, I. 2018. New records of lichens and allied fungi from Lapponia petsamoënsis, Murmansk Region, Russia. Folia Cryptogamica Estonica 55: 1-5. https:/ / doi. org/ 10.12697/fce.2018.55.01

Wirth, V. 1992. Neufunde von Flechten und flechtenbewohnenden Pilzen in Südwest-Deutschland und benachbaren Regionen. Jahreshefte der Gesellschaft für Naturkunde in Württemberg 147: 213-227.

Zhurbenko, M. P. 2002. Lichenicolous fungi from the Polar Ural. Mikologiya i Fitopatologiya 36(6): 9-14.

Zhurbenko, M. P. 2004. Lichenicolous and some interesting lichenized fungi from the Northern Ural, Republic of Komiof Russia. Herzogia 17: 77-86.

Zhurbenko, M. P. 2008. Lichenicolous fungi from Russia, mainly from its Arctic. II. Mycologia Balcanica 5(1-2): 13-22.

Zhurbenko, M. P. 2009a. Lichenicolous fungi and some lichens from the Holarctic. Opuscula Philolichenum 6: 87-120.

Zhurbenko, M. P. 2009b. Lichenicolous fungi and lichens from the Holarctic. Part II. Opuscula Philolichenum 7: 121-186.

Zhurbenko, M. P. \& Ahti, T. 2005. A preliminary list of lichenicolous fungi of Republic of Karelia, Russia. Fungi in natural and anthropogenic ecosystems 1 : 194-200. (in Russian).

Zhurbenko, M. P. \& Alstrup, V. 2004. Lichenicolous fungi on Cladonia mainly from the Arctic. Acta Universitatis Upsaliensis Symbolae Botanicae Upsalienses 34(1): 477-499.

Zhurbenko, M. P. \& Himelbrant, D. E. 2002. Lichenicolous fungi from the Kandalaksha Gulf, Karelia Keretina, Russia. Folia Cryptogamica Estonica 39: 51-59. 
Zhurbenko, M. P. \& Pino-Bodas, R. 2017. A revision of lichenicolous fungi growing on Cladonia, mainly from the Northern Hemisphere, with a worldwide key to the known species. Opuscula Philolichenum 16: 188-266.

Zhurbenko, M. P. \& Santesson, R. 1996. Lichenicolous fungi from the Russian Arctic. Herzogia 12: 147-161.

Zhurbenko, M. P. \& Zhdanov, I. S. 2013. Melaspilea galligena sp. nov. and some other lichenicolous fungi from Russia. Folia Cryptogamica
Estonica 50: 89-99. https://doi.org/10.12697/ fce.2013.50.12

Zhurbenko, M. P. \& Zheludeva, E. V. 2015. Lichenicolous fungi from Russia, mainly from the Magadan Region. Folia Cryptogamica Estonica 52: 101-107. https://doi.org/10.12697/fce.2015.52.13

Zhurbenko, M. P., Hermansson, J. \& Pystina, T. N. 2012. Lichenicolous fungi from the Republic of Komi of Russia. II. Folia Cryptogamica Estonica 49: 89-91.

Appendix. List of collecting sites in the Arkhangelsk Region (see also Fig. 1). Collectors and identifiers: AS - Angella Sonina, AV - Andrey Valekzhanin, ECh - Elena Churakova, LP - Liudmila Puchnina, MZh - Mikhail Zhurbenko, NB - Natalia Burova, NS - Natalia Semenova, TP - Tatiana Pystina, VA - Vera Androsova, VT - Viktoria Tarasova

\begin{tabular}{|c|c|c|c|c|c|c|c|}
\hline No. & & Locality & Coordinates & Altitude & Community & $\begin{array}{l}\text { Collectors, } \\
\text { identifiers }\end{array}$ & Collection date \\
\hline \multirow[t]{15}{*}{ I } & 1 & $\begin{array}{l}\text { Pinezhsky District, upper } \\
\text { reaches of the Njukhcha } \\
\text { River }\end{array}$ & $\begin{array}{l}63^{\circ} 42^{\prime} 12.1 " \mathrm{~N} \\
46^{\circ} 19^{\prime} 13.8^{\prime \prime} \mathrm{E}\end{array}$ & $179 \mathrm{~m}$ & $\begin{array}{l}\text { bilberry feather- } \\
\text { moss spruce forest }\end{array}$ & leg. \& det. VT & 20 June 2019 \\
\hline & 2 & & $\begin{array}{l}63^{\circ} 41^{\prime} 42.9^{\prime \prime} \mathrm{N}, \\
46^{\circ} 19^{\prime} 26.2^{\prime \prime} \mathrm{E}\end{array}$ & $179 \mathrm{~m}$ & $\begin{array}{l}\text { bilberry feather- } \\
\text { moss spruce forest }\end{array}$ & leg. \& det. VT & 19 June 2019 \\
\hline & 3 & & $\begin{array}{l}63^{\circ} 41^{\prime} 49.0 " \mathrm{~N} \\
46^{\circ} 19^{\prime} 43.6^{\prime \prime} \mathrm{E}\end{array}$ & $159 \mathrm{~m}$ & $\begin{array}{l}\text { paludified herb- } \\
\text { rich spruce forest }\end{array}$ & leg. \& det. VT & 19 June 2019 \\
\hline & 4 & & $\begin{array}{l}63^{\circ} 42^{\prime} 08.0^{\prime \prime} \mathrm{N} \\
46^{\circ} 13^{\prime} 24.8^{\prime \prime} \mathrm{E}\end{array}$ & $183 \mathrm{~m}$ & $\begin{array}{l}\text { bilberry feather- } \\
\text { moss spruce forest }\end{array}$ & leg. \& det. VT & 20 June 2019 \\
\hline & 5 & & $\begin{array}{l}63^{\circ} 42^{\prime} 10.6 ” \mathrm{~N} \\
46^{\circ} 19^{\prime} 01.3^{\prime \prime} \mathrm{E}\end{array}$ & $157 \mathrm{~m}$ & $\begin{array}{l}\text { paludified herb- } \\
\text { rich spruce forest }\end{array}$ & $\begin{array}{l}\text { leg. VT, det. } \\
\text { VT, LK \& SCh }\end{array}$ & 21 June 2019 \\
\hline & 6 & & $\begin{array}{l}63^{\circ} 41^{\prime} 40.9^{\prime \prime} \mathrm{N} \\
46^{\circ} 16^{\prime} 50.3^{\prime \prime} \mathrm{E}\end{array}$ & $180 \mathrm{~m}$ & $\begin{array}{l}\text { paludified peat- } \\
\text { moss spruce forest }\end{array}$ & leg. \& det. VT & 21 June 2019 \\
\hline & 7 & & $\begin{array}{l}63^{\circ} 42^{\prime} 27.8^{\prime \prime} \mathrm{N} \\
46^{\circ} 19^{\prime} 56.4^{\prime \prime} \mathrm{E}\end{array}$ & $139 \mathrm{~m}$ & $\begin{array}{l}\text { paludified flood- } \\
\text { plain herb-rich } \\
\text { spruce forest }\end{array}$ & $\begin{array}{l}\text { leg. VT, det. } \\
\text { VT, LK \& SCh }\end{array}$ & 23 June 2019 \\
\hline & 8 & & $\begin{array}{l}63^{\circ} 42^{\prime} 10.6 ” \mathrm{~N} \\
46^{\circ} 20^{\prime} 51.4 ” \mathrm{E}\end{array}$ & $140 \mathrm{~m}$ & $\begin{array}{l}\text { paludified flood- } \\
\text { plain herb-rich } \\
\text { spruce forest }\end{array}$ & $\begin{array}{l}\text { leg. VT, det. } \\
\text { VT, LK \& SCh }\end{array}$ & 24 June 2019 \\
\hline & 9 & & $\begin{array}{l}63^{\circ} 41^{\prime} 0.2^{\prime \prime} \mathrm{N} \\
46^{\circ} 21^{\prime} 4.3^{\prime \prime} \mathrm{E}\end{array}$ & $128 \mathrm{~m}$ & $\begin{array}{l}\text { paludified flood- } \\
\text { plain herb-rich } \\
\text { spruce forest }\end{array}$ & leg. \& det. VT & 24 June 2019 \\
\hline & 10 & & $\begin{array}{l}63^{\circ} 42^{\prime} 27.8^{\prime \prime} \mathrm{N} \\
46^{\circ} 19^{\prime} 56.4 ” \mathrm{E}\end{array}$ & $146 \mathrm{~m}$ & $\begin{array}{l}\text { paludified flood- } \\
\text { plain herb-rich } \\
\text { spruce forest }\end{array}$ & leg. \& det. VT & 22 June 2019 \\
\hline & 11 & & $\begin{array}{l}63^{\circ} 41^{\prime} 19.1^{\prime \prime} \mathrm{N} \\
46^{\circ} 16^{\prime} 42.9^{\prime \prime} \mathrm{E}\end{array}$ & $167 \mathrm{~m}$ & $\begin{array}{l}\text { paludified herb- } \\
\text { rich spruce forest }\end{array}$ & leg. \& det. VT & 21 June 2019 \\
\hline & 12 & & $\begin{array}{l}63^{\circ} 42^{\prime} 37.7^{\prime \prime} \mathrm{N}, \\
46^{\circ} 18^{\prime} 46.0^{\prime \prime} \mathrm{E}\end{array}$ & $142 \mathrm{~m}$ & $\begin{array}{l}\text { paludified flood- } \\
\text { plain herb-rich } \\
\text { spruce forest }\end{array}$ & leg. \& det. VT & 22 June 2019 \\
\hline & 13 & & $\begin{array}{l}63^{\circ} 43^{\prime} 06.4 " \mathrm{~N} \\
46^{\circ} 19^{\prime} 04.5^{\prime \prime} \mathrm{E}\end{array}$ & $144 \mathrm{~m}$ & $\begin{array}{l}\text { paludified peat- } \\
\text { moss spruce forest }\end{array}$ & leg. \& det. VT & 23 June 2019 \\
\hline & 14 & & $\begin{array}{l}63^{\circ} 40^{\prime} 43.8^{\prime \prime} \mathrm{N} \\
46^{\circ} 24^{\prime} 33.5^{\prime \prime} \mathrm{E}\end{array}$ & $167 \mathrm{~m}$ & $\begin{array}{l}\text { bilberry feather- } \\
\text { moss spruce forest }\end{array}$ & leg. \& det. VT & 25 June 2019 \\
\hline & 15 & & $\begin{array}{l}63^{\circ} 40^{\prime} 50.1 " \mathrm{~N} \\
46^{\circ} 22^{\prime} 17.2^{\prime \prime} \mathrm{E}\end{array}$ & $160 \mathrm{~m}$ & $\begin{array}{l}\text { bilberry feather- } \\
\text { moss spruce forest }\end{array}$ & leg. \& det. VT & 25 June 2019 \\
\hline
\end{tabular}


16

17

18

19

20

21

II

22 Onezhsky District, Vetreny Poyas Ridge, Shapochka Mountain

III 23 Onezhsky District, Vodlozersky National Park, Ileksa River basin $46^{\circ} 18^{\prime} 52.3^{\prime \prime} \mathrm{E}$

$63^{\circ} 43^{\prime} 15.7^{\prime \prime} \mathrm{N}, \quad 148 \mathrm{~m}$

$63^{\circ} 41^{\prime} 50.8^{\prime \prime} \mathrm{N}, \quad 177 \mathrm{~m}$ $46^{\circ} 18^{\prime} 32.8^{\prime \prime} \mathrm{E}$

$63^{\circ} 43^{\prime} 25.2^{\prime \prime} \mathrm{N}, \quad 166 \mathrm{~m}$ $46^{\circ} 18^{\prime} 3.4^{\prime \prime} \mathrm{E}$

$63^{\circ} 42^{\prime} 27.7^{\prime \prime} \mathrm{N}, \quad 133 \mathrm{~m}$ $46^{\circ} 20^{\prime} 46^{\prime \prime} \mathrm{E}$

$63^{\circ} 42^{\prime} 34.2^{\prime \prime} \mathrm{N}, \quad 143 \mathrm{~m}$ $46^{\circ} 19^{\prime} 57.8^{\prime \prime} \mathrm{E}$

$63^{\circ} 36^{\prime} 46.3^{\prime \prime} \mathrm{N}, \quad 294 \mathrm{~m}$ $36^{\circ} 25^{\prime} 16.8^{\prime \prime} \mathrm{E}$

$63^{\circ} 02^{\circ} 01.9^{\prime \prime} \mathrm{N}, \quad 172 \mathrm{~m}$ $36^{\circ} 56^{\prime} 42.7^{\prime \prime} \mathrm{E}$

$63^{\circ} 01^{\prime} 57.2^{\prime \prime} \mathrm{N}, \quad 174 \mathrm{~m}$ $36^{\circ} 59^{\prime} 20.5^{\prime \prime} \mathrm{E}$

$63^{\circ} 06^{\prime} 32.1^{\prime \prime} \mathrm{N}, \quad 175 \mathrm{~m}$ $36^{\circ} 48^{\prime} 33.4^{\prime \prime} \mathrm{E}$

6311'04.6” N, $177 \mathrm{~m}$ $36^{\circ} 45^{\prime} 55.2^{\prime \prime} \mathrm{E}$

$62^{\circ} 49^{\prime} 27.8^{\prime \prime} \mathrm{N}, \quad 165 \mathrm{~m}$ $37^{\circ} 05^{\prime} 8.6^{\prime \prime} \mathrm{E}$

$63^{\circ} 10^{\prime} 26.4$ "N,$\quad 225 \mathrm{~m}$ $36^{\circ} 32^{\circ} 01.6^{\prime \prime} \mathrm{E}$

$63^{\circ} 07^{\prime} 29.5^{\prime \prime} \mathrm{N}, \quad 175 \mathrm{~m}$ $36^{\circ} 47^{\prime} 55.2^{\prime \prime} \mathrm{E}$

$63^{\circ} 11^{\prime} 27.2^{\prime \prime} \mathrm{N}, \quad 197 \mathrm{~m}$ $36^{\circ} 23^{\prime} 59.7^{\prime \prime} \mathrm{E}$ $37^{\circ} 00^{\prime} 11.6^{\prime \prime} \mathrm{E}$

$63^{\circ} 15^{\prime} 26.9^{\prime \prime} \mathrm{N}, \quad 178 \mathrm{~m}$ $36^{\circ} 37^{\prime} 50.2^{\prime \prime} \mathrm{E}$

$63^{\circ} 15^{\prime} 26.9^{\prime \prime} \mathrm{N}, \quad 176 \mathrm{~m}$ $36^{\circ} 37^{\prime} 50.2^{\prime \prime} \mathrm{E}$

$63^{\circ} 06^{\prime} 32.1^{\prime \prime} \mathrm{N}, \quad 175 \mathrm{~m}$ $36^{\circ} 48^{\prime} 33.4^{\prime \prime} \mathrm{E}$

$63^{\circ} 30^{\prime} 52^{\prime \prime} \mathrm{N}, \quad 285 \mathrm{~m}$ $36^{\circ} 37^{\prime} 29.7^{\prime \prime} \mathrm{E}$

ersky Nation ern border of the park,

Vetreny Poyas Ridge, Volda
Mountain $63^{\circ} 43^{\prime} 23.9^{\prime \prime} \mathrm{N}, \quad 145 \mathrm{~m}$ $46^{\circ} 18^{\prime} 42.5^{\prime \prime} \mathrm{E}$

$63^{\circ} 01^{\prime} 57.2^{\prime \prime} \mathrm{N}$

paludified flood- leg. \& det. VT 23 June 2019

plain herb-rich

spruce forest

paludified herb- leg. VT, det. 22 June 2019

rich spruce forest VT, LK \& SCh

bilberry feather- leg. \& det. VT 21 June 2019 moss spruce forest

bilberry feather- leg. \& det. VT 23 June 2019 moss spruce forest

paludified flood- leg. VT, det. 24 June 2019

plain herb-rich $\quad$ SCh

spruce forest

paludified flood- leg. VT, det. 22 June 2019

plain herb-rich LK \& SCh

spruce forest

bilberry feather- leg. AV, det. 8 June 2017

moss spruce forest VT

on rock

floodplain herb- leg. VT, det. 9 June 2019 rich spruce forest LK \& SCh

floodplain herb- leg. VA, det. $\quad 5$ June 2019 rich spruce forest $\quad$ LK \& SCh

paludified bilberry leg. VA, VT, 9 June 2019

peatmoss spruce det. LK \& SCh

forest

paludified herb- leg. VA, det. 10 June 2019

rich spruce forest LK \& SCh

paludified bilberry leg. VT, det. 7 June 2019

peatmoss spruce LK \& SCh

forest

bilberry feather- leg. VT, det. 1 June 2019

moss spruce forest LK \& SCh

bilberry feather- leg. VT, det. 10 June 2019

moss spruce forest LK \& SCh

young (25 years leg. VT, det. 1 June 2019

after clear cutting) LK \& SCh

herb-rich birch

forest

floodplain herb- leg. VA, det. 5 June 2019

rich spruce forest $\quad$ LK \& SCh

horsetail peatmoss leg. VT, det. 11 June 2019

spruce forest LK \& SCh

paludified herb- leg. VA, det. 10 June 2019

rich spruce forest LK \& SCh

paludified bilberry leg. VA; det. 9 June 2019

peatmoss spruce LK \& SCh

forest

bilberry feather- $\quad$ leg. \& det. VT 11 June 2018 moss spruce forest

$63^{\circ} 30^{\prime} 52^{\prime \prime} \mathrm{N}, \quad 302 \mathrm{~m}$ $36^{\circ} 37^{\prime} 29.7^{\prime \prime} \mathrm{E}$ moss spruce forest bilberry feather- leg. \& det. VT 11 June 2018 on rock 
V 37 Onezhsky District, Vodlozersky National Park, western coast of Kalgachinskoe Lake

VI 38 Onezhsky District, Vodlozersky National Park, 4 km to the west of Kalgachinskoe Lake, Muroigora Mountain

VII 40 Onezhsky District, Vodlozersky National Park, $1 \mathrm{~km}$ upstream from the mouth of the Olova River

VIII 41 Onezhsky District, Vodlozersky National Park, near abandoned Kalgachikha village

IX 42 Onezhsky District, Vodloz- 6325’29”N, ersky National Park, eastern $36^{\circ} 37^{\prime} 38^{\prime \prime} \mathrm{E}$ bank of Verkhnyaya River, near Kerazh cabin

X 43 Onezhsky District, Vodlozersky National Park, 3.2 $\mathrm{km}$ NNW of abandoned Kalgachikha village, between Ulozero and Zadnee Lakes

XI 44 Onezhsky District, Vodlozersky National Park, 3.5 km NNW of abandoned Kalgachikha village, southern shore of Zadnee Lake

XII 45 Onezhsky District, Vetreny Poyas Ridge, Olovgora Mountain

$63^{\circ} 21^{\prime} 17^{\prime \prime} \mathrm{N}$ $36^{\circ} 43^{\prime} 25^{\prime \prime} \mathrm{E}$

$63^{\circ} 21^{\prime} 06^{\prime \prime} \mathrm{N}$ $36^{\circ} 43^{\prime} 28^{\prime \prime} \mathrm{E}$ 633' $24 " \mathrm{~N}$, $63^{\circ} 16^{\prime} 15^{\prime \prime} \mathrm{N}$, 3639'49"E

$63^{\circ} 19^{\prime} 46^{\prime \prime} \mathrm{N}$, $36^{\circ} 42$ ' $18^{\prime \prime} \mathrm{E}$

$173 \mathrm{~m}$

floodplain willow forest

lichen-feathermoss spruce fores

leg. AS, det.

$224 \mathrm{~m}$

190 m hillside

$187 \mathrm{~m}$

floodplain herbrich spruce forest

leg. ECh, det $\mathrm{MZh}$

$195 \mathrm{~m}$

herbal-rich birchaspen forest

leg. TP, det. $\mathrm{MZh}$

leg. ECh, det. $\mathrm{MZh}$

leg. TP
MZh

leg. ECh, det. 4 July 2016 $\mathrm{MZh}$

moss spruce forest

on rock

eg. TP, det.

$\mathrm{MZh}$

1 July 2016

9 June 2011

6 July 2016 $37^{\circ} 00^{\prime} 15^{\prime \prime} \mathrm{E}$

$327 \mathrm{~m}$

$63^{\circ} 2435^{\prime \prime} \mathrm{N}$ $37^{\circ} 00^{\prime} 11^{\prime \prime} \mathrm{E}$

$320 \mathrm{~m}$

6317'09”N, $226 \mathrm{~m}$ 363' $30^{\prime \prime} \mathrm{E}$ ersky National Park, Roin' Gora hill

XIV 48 Onezhsky District, Vodlozersky National Park, foot of Bab'ya Gora hill

XV 49 Plesetsky District, mouth of the Netoma River

XVI 50 Krasnoborsky District, the right bank of the Lakhoma River, $3.24 \mathrm{~km}$ from the mouth of the Istok River

XVII 51 Krasnoborsky District, the left bank of the Lakhoma River, $2.8 \mathrm{~km}$ from the mouth of the Istok River $63^{\circ} 17^{\prime} 58^{\prime \prime} \mathrm{N}, \quad 226 \mathrm{~m}$ $36^{\circ} 40^{\prime} 55^{\prime \prime} \mathrm{E}$

$62^{\circ} 13^{\prime} 28.4$ 'N,$\quad 84 \mathrm{~m}$ $37^{\circ} 28^{\prime} 04.2^{\prime \prime} \mathrm{E}$

$61^{\circ} 50^{\prime} 50.8^{\prime \prime} \mathrm{N}, \quad 56 \mathrm{~m}$ $46^{\circ} 00^{\prime} 14.2^{\prime \prime} \mathrm{E}$

6150'44.6”N, $53 \mathrm{~m}$ $45^{\circ} 59^{\prime} 58.4$ " E bilberry feathermoss birchspruce-pine forest

leg. TP, det. $\mathrm{MZh}$

2 July 2016

lichen-feather moss spruce forest on rock

lichen-feathermoss spruce forest on rock

bilberry feathermoss pine forest on rock

herb-rich aspen forest

floodplain herbrich spruce-birch forest

linden-aspen for- leg. \& det. NS 2 August 2019 est with nearly dead ground layer vegetation

fern-monkshood linden-birchspruce forest leg. AS, det. 8 July 2013

$\mathrm{MZh}$

leg. VT, det.

6 June 2012

leg. TP, det. $\mathrm{MZh}$

6 July 2016

leg. TP, det. $\mathrm{MZh}$

6 July 2016

leg. VT, det.

16 July 2019

leg. \& det. NS

2 August 2019 
XVIII 52 Krasnoborsky District, floodplain of the Severnaya Dvina River, the right bank of the river, $12 \mathrm{~km}$ to the north-west from Dyabrino village

XIX 53 Krasnoborsky District, 14 $\mathrm{km}$ to the north from Bolshaya Sludka village, $400 \mathrm{~m}$ northeast of the forest road, near swamp

XX 54 Krasnoborsky District, Krasnoborskoe forestry, Komarovskoe regional forest district, quarter 32 55

XXI 56 Onezhsky District, Onezhsky peninsula, Onezhskoe forestry, Nizhmozerskoe regional forest district, quarter 112

XXII 57 Verkhnetoyemsky District, near Lambas village, Vujskoe forestry, Gorkovskoe regional forest district, quarter 145,167

XXIII 60 Leninsky District, near Shies railway station

61

62
613'33.1”N, $70 \mathrm{~m}$ $45^{\circ} 467.6$ ” $\mathrm{E}$

$61^{\circ} 43^{\prime} 52.4 ” \mathrm{~N}, \quad 77 \mathrm{~m}$ $46^{\circ} 00^{\prime} 45.0$ ”'E

6206'55.22” N, $175 \mathrm{~m}$ $47^{\circ} 22^{\prime} 30.6^{\prime \prime} \mathrm{E}$

$62^{\circ} 07^{\prime} 16.3^{\prime \prime} \mathrm{N}, \quad 168 \mathrm{~m}$ $47^{\circ} 22^{\prime} 47.3$ ” E

$64^{\circ} 27^{\prime} 10.3^{\prime \prime} \mathrm{N}, \quad 84 \mathrm{~m}$ $37^{\circ} 12^{\prime} 31.6^{\prime \prime} \mathrm{E}$

$64^{\circ} 27^{\prime} 10.3^{\prime \prime} \mathrm{N}, \quad 153 \mathrm{~m}$ $34^{\circ} 12^{\prime} 31.6$ ”E

62.49'01.9”N, $173 \mathrm{~m}$ $45^{\circ} 32^{\prime} 01.7$ ” E

$62^{\circ} 49^{\prime} 0.3$ " N, $173 \mathrm{~m}$ $45^{\circ} 33^{\prime} 52.5^{\prime \prime} \mathrm{E}$

$61^{\circ} 53^{\prime} 12.6^{\prime \prime} \mathrm{N}, \quad 126 \mathrm{~m}$ $49^{\circ} 5^{\prime} 12.9^{\prime \prime} \mathrm{E}$

$61^{\circ} 53^{\prime} 14.5^{\prime \prime} \mathrm{N}, \quad 120 \mathrm{~m}$ $49^{\circ} 04^{\prime} 10.5^{\prime \prime} \mathrm{E}$

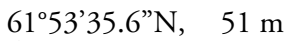
$49^{\circ} 05^{\prime} 28.8^{\prime \prime} \mathrm{E}$

$61^{\circ} 53^{\prime} 32.3 ” \mathrm{~N}, \quad 17 \mathrm{~m}$ $49^{\circ} 06^{\prime} 04.0$ ”'E

6152'56.6”N, $135 \mathrm{~m}$ $49^{\circ} 04^{\prime} 53.6$ " E

$61^{\circ} 53^{\prime} 26.4 ” \mathrm{~N}, \quad 54 \mathrm{~m}$ $49^{\circ} 03^{\prime} 30.0$ ”'E

$61^{\circ} 53$ '20.1”N, $54 \mathrm{~m}$ $49^{\circ} 05^{\prime} 52.8^{\prime \prime} \mathrm{E}=$ paludified flood-

plain herb-rich

spruce-black alder

forest

paludified marsh tea peatmoss pine

forest

leg. \& det. NS 5 August 2019

old growth bil-

berry feathermoss spruce forest

leg. NB, det. 10 August

TP

2017

old-growing bil-

berry feathermoss

leg. NB, det.

TP

11 August

spruce forest

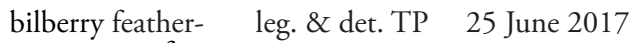
moss spruce forest

bilberry feather- leg. NB, det. 6 August 2018 moss spruce forest $\mathrm{TP}$

bilberry feathermoss spruce forest, source of the stream

paludified flood- leg. NB, det. 5 August 2018 plain herb-rich spruce-black alder forest

bilberry feathermoss pine forest

leg. NB, det. $\quad 5$ August 2018 TP

TP

pine forests, along leg. \& det. TP, 7 June 2019 the edges of raised NS bogs

sorrel peatmoss $\quad$ leg. \& det. TP, 7 June 2019 spruce forest NS

old-growth palu- leg. \& det. TP, 8 June 2019 dified peatmoss NS spruce forest

bilberry peatmoss leg. \& det. TP, 8 June 2019 spruce forest, along the edges of raised bogs

shrub horsetail leg. \& det. TP, 9 June 2019 peatmoss spruce NS forest

sorrel peatmoss leg. \& det. TP, 9 June 2019 spruce forest

NS

